Cochrane Database of Systematic Reviews

\title{
Methadone for cancer pain (Review)
}

Nicholson AB, Watson GR, Derry S, Wiffen PJ

Nicholson AB, Watson GR, Derry S, Wiffen PJ.

Methadone for cancer pain.

Cochrane Database of Systematic Reviews 2017, Issue 2. Art. No.: CD003971.

DOI: 10.1002/14651858.CD003971.pub4.

www.cochranelibrary.com 
HEADER

ABSTRACT

PLAIN LANGUAGE SUMMARY

SUMMARY OF FINDINGS

BACKGROUND

OBJECTIVES

METHODS

Figure 1.

Figure 2.

Figure 3.

RESULTS

DISCUSSION

AUTHORS' CONCLUSIONS

ACKNOWLEDGEMENTS

REFERENCES

CHARACTERISTICS OF STUDIES

APPENDICES

WHAT'S NEW

HISTORY

CONTRIBUTIONS OF AUTHORS

DECLARATIONS OF INTEREST

SOURCES OF SUPPORT

DIFFERENCES BETWEEN PROTOCOL AND REVIEW

NOTES

INDEX TERMS

\section{TABLE OF CONTENTS}

1

1

2

3

5

6

6

8

10

11

13

14

15

15

16

18

25

30

30

30

30

30

31

31

31 
[Intervention Review]

\section{Methadone for cancer pain}

Alexander B Nicholson¹, Graeme R Watson¹, Sheena Derry², Philip J Wiffen²

1South Tees Hospitals NHS Foundation Trust, Middlesbrough, UK. 2Pain Research and Nuffield Department of Clinical Neurosciences (Nuffield Division of Anaesthetics), University of Oxford, Oxford, UK

Contact address: Alexander B Nicholson, South Tees Hospitals NHS Foundation Trust, Middlesbrough, TS4 3BW, UK. alex.nicholson@nhs.net, alexander@doctors.org.uk.

Editorial group: Cochrane Pain, Palliative and Supportive Care Group.

Publication status and date: Edited (no change to conclusions), published in Issue 3, 2017.

Citation: Nicholson AB, Watson GR, Derry S, Wiffen PJ. Methadone for cancer pain. Cochrane Database of Systematic Reviews 2017, Issue 2. Art. No.: CD003971. DOI: 10.1002/14651858.CD003971.pub4.

Copyright @ 2017 The Cochrane Collaboration. Published by John Wiley \& Sons, Ltd.

\section{A B S T R A C T}

\section{Background}

This is an updated review originally published in 2004 and first updated in 2007. This version includes substantial changes to bring it in line with current methodological requirements. Methadone is a synthetic opioid that presents some challenges in dose titration and is recognised to cause potentially fatal arrhythmias in some patients. It does have a place in therapy for people who cannot tolerate other opioids but should be initiated only by experienced practitioners. This review is one of a suite of reviews on opioids for cancer pain.

\section{Objectives}

To determine the effectiveness and tolerability of methadone as an analgesic in adults and children with cancer pain.

\section{Search methods}

For this update we searched CENTRAL, MEDLINE, Embase, CINAHL, and clinicaltrials.gov, to May 2016, without language restriction. We also checked reference lists in relevant articles.

\section{Selection criteria}

We sought randomised controlled trials comparing methadone (any formulation and by any route) with active or placebo comparators in people with cancer pain.

\section{Data collection and analysis}

All authors agreed on studies for inclusion. We retrieved full texts whenever there was any uncertainty about eligibility. One review author extracted data, which were checked by another review author. There were insufficient comparable data for meta-analysis. We extracted information on the effect of methadone on pain intensity or pain relief, the number or proportion of participants with 'no worse than mild pain'. We looked for data on withdrawal and adverse events. We looked specifically for information about adverse events relating to appetite, thirst, and somnolence. We assessed the evidence using GRADE and created a 'Summary of findings' table.

\section{Main results}

We revisited decisions made in the earlier version of this review and excluded five studies that were previously included. We identified one new study for this update. This review includes six studies with 388 participants. We did not identify any studies in children.

The included studies differed so much in their methods and comparisons that no synthesis of results was feasible. Only one study (103 participants) specifically reported the number of participants with a given level of pain relief, in this case a reduction of at least $20 \%$ similar in both the methadone and morphine groups. Using an outcome of 'no worse than mild pain', methadone was similar to morphine in effectiveness, and most participants who could tolerate methadone achieved 'no worse than mild pain'. Adverse event withdrawals 
with methadone were uncommon (12/202) and similar in other groups. Deaths were uncommon except in one study where the majority of participants died, irrespective of treatment group. For specific adverse events, somnolence was more common with methadone than with morphine, while dry mouth was more common with morphine than with methadone. None of the studies reported effects on appetite.

We judged the quality of evidence to be low, downgraded due to risk of bias and sparse data. For specific adverse events, we considered the quality of evidence to be very low, downgraded due to risk of bias, sparse data, and indirectness, as surrogates for appetite, thirst and somnolence were used.

There were no data on the use of methadone in children.

\section{Authors' conclusions}

Based on low-quality evidence, methadone is a drug that has similar analgesic benefits to morphine and has a role in the management of cancer pain in adults. Other opioids such as morphine and fentanyl are easier to manage but may be more expensive than methadone in many economies.

\section{PLAIN LANGUAGE SUMMARY}

Methadone (an opioid drug) for treating people with cancer pain

\section{Bottom line}

Methadone taken by mouth provided good pain relief for most adults with moderate or severe cancer pain.

\section{Background}

One person in two or three who gets cancer will suffer from pain that becomes moderate or severe in intensity. The pain tends to get worse as the cancer progresses. Methadone has been used for many years as one of a number of different pain killers for cancer pain.

\section{Study characteristics}

In this updated review we set out to estimate how well methadone worked, how many people had side effects, and how severe those side effects were - for example, whether they were so severe that participants stopped taking their methadone.

In May 2016, we found just six studies with 388 adult participants. The studies were often small, and compared different preparations.

\section{Key findings}

For pain relief there did not seem to be much difference between methadone and morphine. For most people pain was reduced from moderate or severe to mild or no pain with methadone. Methadone is associated with some unwanted effects, mainly sleepiness, constipation, and dry mouth. These can be severe enough to stop people taking methadone. No data were available about the use of methadone in children.

We would like to see more consistency in study design, and especially in study reporting, which should include information on unwanted effects and the outcome of pain reduced to tolerable levels, that is, no worse than mild pain, so that people with cancer are not bothered by pain.

\section{Quality of the evidence}

We rated the quality of the evidence from studies using four levels: very low, low, moderate, or high. Very low quality evidence means that we are very uncertain about the results. High quality evidence means that we are very confident in the results. The quality of the evidence was low or very low. 
SUMMARY OF FINDINGS

Summary of findings for the main comparison. Methadone compared to Morphine for cancer pain

Methadone compared to morphine for cancer pain

Patient or population: people with cancer pain

Intervention: methadone

Comparison: morphine

\begin{tabular}{|c|c|c|c|c|c|c|}
\hline \multirow[t]{2}{*}{ Outcomes } & Assumed risk & Corresponding risk & \multirow{2}{*}{$\begin{array}{l}\text { Relative effect } \\
(95 \% \mathrm{Cl})\end{array}$} & \multirow{2}{*}{$\begin{array}{l}\text { No of participants } \\
\text { (studies) }\end{array}$} & \multirow{2}{*}{$\begin{array}{l}\text { Quality of the } \\
\text { evidence } \\
\text { (GRADE) }\end{array}$} & \multirow[t]{2}{*}{ Comments } \\
\hline & Morphine & Methadone & & & & \\
\hline $\begin{array}{l}\text { Participant-re- } \\
\text { ported pain in- } \\
\text { tensity }\end{array}$ & \multicolumn{4}{|c|}{$\begin{array}{l}\text { Pain intensity scores: } \\
\text { One study (103 participants) reported }>20 \% \text { improvement in pain scores for } 76 \% \text { of morphine and } 75 \% \\
\text { methadone participants in those that completed } \\
\text { No worse than mild pain (pain score of } \mathbf{3 / 1 0} \text { or less after treatment): } \\
\text { One study ( } 54 \text { participants) reported all achieved no worse than mild pain based on mean pain scores. Two studies } \\
\text { (148 participants) reported mean pain scores very close to a score of } 3\end{array}$} & $\begin{array}{l}\oplus \oplus \oplus \ominus \\
\text { low } 1,2\end{array}$ & $\begin{array}{l}\text { Downgraded } \\
\text { two points for } \\
\text { reasons stated }\end{array}$ \\
\hline $\begin{array}{l}\text { Adverse } \\
\text { events: ap- } \\
\text { petite, thirst, } \\
\text { somnolence }\end{array}$ & Not estimable & Not estimable & Not estimable & $\begin{array}{l}342 \\
\text { (5 studies) }\end{array}$ & $\begin{array}{l}\oplus \odot \odot \odot \\
\text { very low 1,2,3 }\end{array}$ & $\begin{array}{l}\text { Downgraded } \\
\text { three points for } \\
\text { reasons stated }\end{array}$ \\
\hline
\end{tabular}

*The basis for the assumed risk (e.g. the median control group risk across studies) is provided in footnotes. The corresponding risk (and its $95 \%$ confidence interval) is based on the assumed risk in the comparison group and the relative effect of the intervention (and its $95 \% \mathrm{Cl}$ ).

Cl: Confidence interval; RR: Risk ratio

GRADE Working Group grades of evidence

High quality: we are very confident that the true effect lies close to that of the estimate of the effect

Moderate quality: we are moderately confident in the effect estimate; the true effect is likely to be close to the estimate of effect, but there is a possibility that it is substantially different

Low quality: our confidence in the effect estimate is limited; the true effect may be substantially different from the estimate of the effect

Very low quality: we have very little confidence in the effect estimate; the true effect is likely to be substantially different from the estimate of effect

1 Risk of bias: random allocation and allocation concealment unclear, all had sample size of less than 200 per treatment arm. 
Imprecision: sample size is smaller than optimal information size; confidence interval around estimate of effect is wide and included no effect and appreciable benefit/harm. Indirectness. Surrogates for appetite, thirst and somnolence such as sedation, drowsiness and dry mouth used. 


\section{B A C K G R O U N D}

This is the second update of the review entitled 'Methadone for Cancer Pain' first published in 2004, and updated in 2007 (Nicholson 2007). This version includes substantial changes to bring it in line with current methodological requirements for Cochrane reviews. This review is one of a suite of reviews on opioids for cancer pain.

\section{Description of the condition}

Cancer-related pain is a common problem. Worldwide prevalence data almost two decades ago suggested that there were 17 million people living with cancer (Payne 1998). Assessments of the prevalence of pain from nationwide studies in different countries have revealed consistent results, indicating that $30 \%$ to $40 \%$ of patients in active therapy experience pain, with this rate increasing to $70 \%$ to $90 \%$ in patients with advanced and progressive disease. Van den Beuken-van Everdingen estimated a prevalence of pain in excess of $50 \%$ for patients at all stages and with all types of cancer (van den Beuken-van Everdingen 2007).

Cancer-related pain may be caused by the tumour pressing on adjacent organs/tissues, or by the tumour invading the tissue and damaging it.

Pain has a significant impact on function. Uncontrolled pain is incompatible with satisfactory quality of existence and it is well recognised that persistent pain impairs daily life and social interaction. Studies highlight the increased risk of anxiety, depression and even suicidal ideation in patients with uncontrolled pain (Graner 2016).

\section{Description of the intervention}

Methadone is a synthetic opioid in the structural class of diphenylpropylamines, which was developed in the 1930s. It is a potent agonist at the mu-opioid and delta-opioid receptors. The high affinity of methadone for mu-receptors (key mediators in supra-spinal analgesia) and delta-receptors (probably important in spinal analgesia) has resulted in it being recommended for use as an analgesic in cancer pain.

Most clinical practice and research in most countries uses a racaemic mixture of two isomers, levorotatory $(\mathrm{L})$ methadone and dextrorotatory (D) methadone, although in Germany L-methadone alone is used (Bruera 2002). L-methadone is 8 to 50 times more potent than D-methadone in humans and is believed to be almost entirely responsible for its analgesic properties (Fainsinger 1993).

Methadone is available as a lipophilic hydrochloride salt and is available as formulations for oral, rectal and parenteral administration (Fainsinger 1993; Ripamonti 1997). It is well absorbed by all routes. Oral administration is followed by rapid gastrointestinal absorption with measurable plasma levels at 30 minutes. The peak plasma levels after an oral dose occur at four hours and begin to decline 24 hours after dosing. Oral bioavailability is high, generally over $85 \%$ ( $79 \% \pm 21$ in studies). The recommended dose to be given parenterally is between $50 \%$ and $80 \%$ of the oral dose (Gannon 1997; Davis 2001). Although local toxicity associated with subcutaneous administration has been reported (Bruera 1991), in many cases this is manageable (Mathew 1999).
Elimination of methadone is mediated by hepatic oxidative biotransformation, renal $\mathrm{N}$-demethylation, and urinary and faecal clearance. Chronic administration results in increased metabolite to methadone ratios, suggesting that autoinduction of hepatic microsomal enzymes occurs. Renal impairment is not thought to impair clearance; methadone may be useful in the management of pain in patients with renal failure. Some drug interactions are significant (Davis 2001).

Methadone has also been demonstrated in animal studies to have antagonist activity at the N-methyl-D-aspartate (NMDA) receptor, resulting in interest in the clinical application of the drug in neuropathic pain syndromes. A combination of NMDA receptor antagonism and opioid agonism might provide valuable analgesic effects with fewer side effects than other analgesics (Gorman 1997).

\section{How the intervention might work}

Single dose studies have shown potency marginally greater than morphine; repeated administration results in greater potency. Methadone's properties of high oral bioavailability, rapid onset of analgesic effect, long half-life (resulting in infrequent dosing schedules), lack of active metabolites, low rate of induction of tolerance, and low cost are characteristics that result in its use in the management of pain in cancer patients (Fainsinger 1993; Hanks 1998; Twycross 1998).

The perceived drawbacks of methadone include high potential for accumulation leading to delayed toxicity, highly variable pharmacokinetics between individuals, relative ease of use of modified-release morphine preparations, possible drug interactions, and concerns over dose titration and conversion from other opioids (Fainsinger 1993). Potential side effects of methadone include constipation, drowsiness, confusion, nausea, hypotension, miosis (constriction of pupils), antidiuresis, exacerbation of asthma, and respiratory depression. Clinical situations where particular caution is advised include:

1. use in the elderly;

2. pain only partially responsive to methadone, where there is a risk of rapid dose escalation;

3. pain thought to have a predominantly psychological component; and

4. people in whom sensitivity to low doses of opioids has previously been demonstrated.

Particular concern has grown in recent years about two aspects of methadone pharmacology: interactions with other drugs and also the potential for prolongation of the QT interval (a measure of cardiac function) resulting in the potentially fatal arrhythmia called torsade de pointes (van den Beuken-van Everdingen 2013). Weschules, Bain and Richeimer (Weschules 2008) conducted a systematic review of the literature to quantify the available evidence relating to methadone-related drug interactions. They concluded that the evidence base was not well developed and much of the available literature consisted of case reports and case series considering inpatients being managed on methadone maintenance treatment programmes for opioid substance misuse. These patients had a high rate of HIV infection (and associated prescribing) and many of them were tobacco smokers with consequent potential induction of the cytochrome P1A2 enzyme, which may confound conclusions. Whilst the authors urge caution in extrapolating the findings of their review to the chronic 
and cancer pain patient populations, they draw attention to possible interactions of interest to pain management clinicians in a table summarising those attributed to interactions with anticonvulsants (phenytoin, phenobarbital and carbamazepine), selective serotonin reuptake inhibitor (SSRI) antidepressants (fluvoxamine, fluoxetine, paroxetine, sertraline and citalopram), tricyclic antidepressants (desipramine, amitriptyline, imipramine) and benzodiazepine anxiolytics (diazepam and alprazolam) (Weschules 2008). They also highlight concern that genetic polymorphism associated with the cytochrome-P enzymes may have a bearing on both methadone metabolism per se, and the occurrence - and potential severity - of methadone-related drug interactions.

Following reports of sudden death in people taking methadone in the early to mid 2000s, interest in prolongation of the QT interval by methadone has arisen. This risk has received specific attention in published guidance about use of methadone for pain in cancer and palliative care patients. For example, the editors of the Palliative Care Formulary (Twycross 2014) included a specific reference to methadone risks in the chapter on QT prolongation in the Fourth Edition which was not present in the Third edition. Cruciani reviewed the available literature in an attempt to answer the questions of whether, and when, ECG examination should be undertaken in patients prescribed methadone (Cruciani 2008). From an examination of available studies published between 1973 and 2007, and considering the evidence in favour of performing ECG testing set against those that raise questions about the significance of cardiac toxicity related to methadone, it was concluded that there are reasons to be cautious and a low threshold for recommending ECG testing is advised. Pending further evidence, Cruciani's recommendations are that ECG examination should be conducted at baseline (methadone initiation), on dose escalation and on addition of relevant medication in the following situations:

1. patients co-administered methadone with drugs that are substrates of the cytochrome-P3A4 or cytochrome-P2D26 enzymes;

2. patients treated with drugs which may block the HERG (human ether-a-go-go related gene) protein in the potassium channel of cardiac tissue, including some macrolide antibiotics (erythromycin, clarithromycin), antipsychotics (chlorpromazine, haloperidol, olanzapine, risperidone) and antidepressants (tricyclics and sertraline and venlafaxine);

3. patients who are medically frail or who have other risk factors for prolonged QT interval including cardiac disease, hypokalaemia, hypomagnesaemia and family history of sudden death.

The Palliative Care Formulary seeks to put this into a clinical context (Twycross 2014), also recommending baseline ECG and repeated ECG on dose titration or other relevant circumstances, with methadone discontinuation in favour of an alternative opioid being advocated if the QT interval is prolonged to greater than 500 $\mathrm{ms}$. The authors do emphasise the need for clinical judgment over the balance of burden versus benefit when weighing the risk, and the importance of communication of this with the patient and those close to them.

\section{Why it is important to do this review}

Methadone is considered to be a useful analgesic for the management of moderate to severe cancer pain. The earlier review in 2007 indicated that it had similar efficacy to morphine, but adverse events may be problematic with repeated dosing, based on limited evidence. Standards for systematic reviews have strengthened since then and it is important to identify any new studies and reassess the evidence for methadone's place in managing cancer pain.

This review is one of a suite of reviews on cancer pain and will be incorporated into an overview of opioids for cancer pain.

\section{O B JECTIVES}

To determine the effectiveness and tolerability of methadone as an analgesic in adults and children with cancer pain.

\section{METHODS}

\section{Criteria for considering studies for this review \\ Types of studies}

We searched for randomised controlled trials (RCTs). We required full journal publication, with the exception of online clinical trial results summaries of otherwise unpublished clinical trials and abstracts with sufficient data for analysis. We did not include short abstracts (usually meeting reports). In this update we excluded studies with treatment groups of fewer than 10 participants.

\section{Types of participants}

\section{Inclusion criteria}

1. Male and female adults and children with cancer pain

2. Any pain with a malignant etiology

3. Etiology may be primary or secondary malignancy, solid or haematological tumours

4. Pain of at least moderate intensity

5. Participants being treated in any setting

\section{Exclusion criteria}

1. People taking methadone for suppression of cough

2. People taking, or who have previously taken, methadone for rehabilitation from opioid dependence

\section{Types of interventions}

1. Methadone given specifically for relief of cancer-related pain, at any dose and by any route

2. Methadone compared with placebo or any other active comparison

\section{Types of outcome measures}

We sought to asses the outcome of 'no worse than mild pain' and the impact of methadone on consciousness, appetite and thirst. These are issues of concern to patients and their relatives and care providers, highlighted in the UK but of international relevance. (DH 2013; Ma 2016; Wiffen 2014).

\section{Primary outcomes}

1. Participant-reported pain intensity or pain relief, or both, measured using a visual analogue scale, verbal rating scale or numerical rating scale

2. Participants with 'no worse than mild pain' on treatment 
We did not use physician or carer assessments of pain.

\section{Secondary outcomes}

1. Participants with adverse events. We collected information on all reported adverse events, but were particularly interested in consciousness; drowsiness and confusion; loss of appetite; thirst; constipation; nausea and vomiting; and respiratory effects.

2. Withdrawals for any reason including non-compliance, adverse events, and death

\section{Search methods for identification of studies}

We searched electronic databases for published studies and clinicaltrails.gov for unpublished studies.

\section{Electronic searches}

For this update we searched the four databases listed below, without language restrictions.

1. The Cochrane Central Register of Controlled Trials (CENTRAL) (via Cochrane Register of Studies Online) on 4 May 2016

2. MEDLINE (via Ovid) January 2006 to 4 May 2016

3. Embase (via Ovid) January 2006 to 4 May 2016

\section{CINAHL (via EBSCO) to 4 May 2016}

For the original review in 2004 and the first update in 2007, we also searched CancerLit, which has been retired and the Cochrane Pain, Palliative and Supportive Care Trials Register, which is no longer updated.

The search strategies for the four databases can be found in Appendix 1.

\section{Searching other resources}

For this update, we searched the clinical trials registry ClinicalTrials.gov up to May 2016.

\section{Data collection and analysis}

\section{Selection of studies}

PW and SD independently screened the title and abstract (where available) of all studies identified by the searches and selected studies that appeared to satisfy the inclusion criteria. Where there was any uncertainty, we requested the full text. We also reviewed all the included studies from the 2007 version of the review. All authors agreed the studies to be included. See Figure 1 for a flow chart of the screening process (Moher 2009). 
Figure 1. Study flow diagram

9 studies included
in earlier review
1 study excluded
from earlier review

48 studies

identified in

CENTRAL

130 studies

identified in

MEDLINE

116 studies

identified in

Embase

59 studies

identified in

CINAHL
2 records identified in clinical trials registries

Excluded

4 studies included

in earlier review

(fewer than 10

participants per

treatment arm (3),

only $15 / 90$ had

cancer-related

pain (1))

1 study excluded

from earlier review

(specifically

excluded

neuropathic pain

due to cancer)

3 studies

identified by

database

searches (used

methadone in

combination with

other agents (2),

not trial of

methadone (1))

2 studies

identified in

clinical trials

registries

(recruited fewer

than 10 
Figure 1. (Continued)

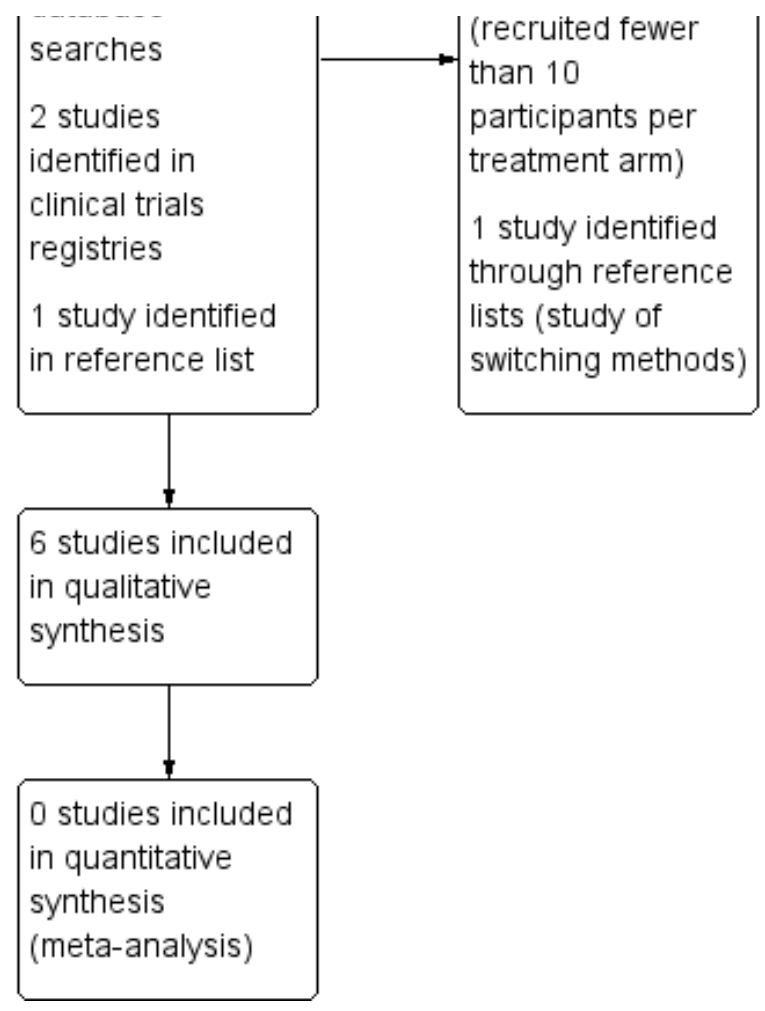

\section{Data extraction and management}

One author extracted data from the included studies into a standardised data collection sheet to include, where available:

1. publication details;

2. method, including trial design, allocation concealment, blinding and duration;

3. patient demographic details - population, number of patients, age, sex, location of study (inpatient or outpatient);

4. details of malignant primary and secondary diagnoses, and previous and current drug history;

5. details of pain characteristics and types, range of intensity and how determined, assessed and documented;
6. description of the intervention (route, dose, etc) and control;

7. measures of effect (e.g. patient-reported pain scores, patient satisfaction, quality-of-life scores);

8. adverse events, withdrawals, and dropouts.

A second author checked the data extraction before entry into Cochrane software Review Manager (RevMan 2014).

\section{Assessment of risk of bias in included studies}

All authors assessed all included studies for risk of bias using the criteria outlined in the Cochrane Handbook for Systematic Reviews of Interventions, and resolved any disagreements by discussion (Higgins 2011). The effect of risk of bias for included studies is shown in Figure 2 and Figure 3. 
Figure 2. Risk of bias graph: review authors' judgements about each risk of bias item presented as percentages across all included studies

Random sequence generation (selection bias)

Allocation concealment (selection bias)

Blinding of participants and personnel (performance bias)

Blinding of outcome assessment (detection bias)

Incomplete outcome data (attrition bias)

Selective reporting (reporting bias)

Size

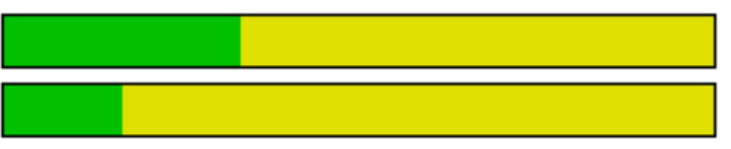

L

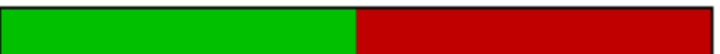

$$
\text { L }
$$
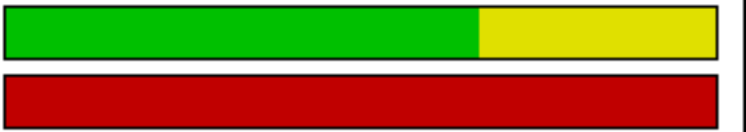

\begin{tabular}{|lllll}
\hline 1 & & 1 & 1 & \\
\hline $0 \%$ & $25 \%$ & $50 \%$ & $75 \%$ & $100 \%$
\end{tabular}


Figure 3. Risk of bias summary: review authors' judgements about each risk of bias item for each included study

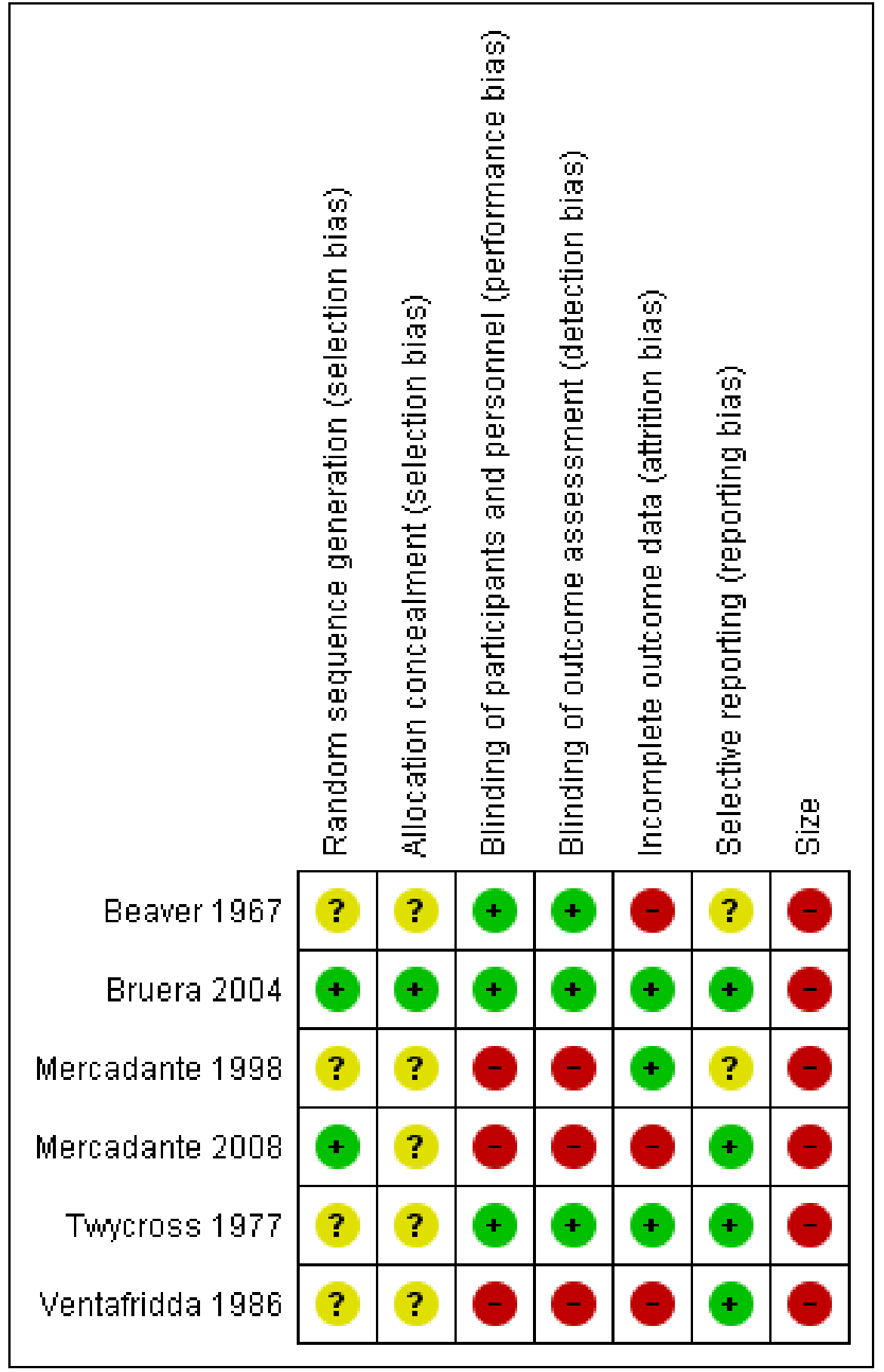

We assessed the following for each study.

1. Random sequence generation (checking for possible selection bias). We assessed the method used to generate the allocation sequence as: low risk of bias (any truly random process: random number table; computer random number generator); unclear risk of bias (method used to generate sequence not clearly stated). We excluded studies using a nonrandom process, which were therefore at high risk of bias (odd or even date of birth; hospital or clinic record number).
2. Allocation concealment (checking for possible selection bias). The method used to conceal allocation to interventions before assignment determines whether the intervention allocation could have been foreseen in advance of, or during recruitment, or changed after assignment. We assessed the methods as: low risk of bias (telephone or central randomisation; consecutivelynumbered sealed opaque envelopes); unclear risk of bias (method not clearly stated). We excluded studies that did not conceal allocation, which were therefore at high risk of bias (open list). 
3. Blinding of participants, personnel, and outcome assessments (checking for possible performance and detection bias). We assessed the methods used to blind study participants, personnel, and outcome assessors from knowledge of which intervention a participant received. We assessed the methods as: low risk of bias (study stated that it was blinded and described the method used to achieve blinding: identical tablets; matched in appearance and smell); unclear risk of bias (study stated that it was blinded but did not provide an adequate description of how blinding was achieved); high risk of bias (study not blinded).

4. Incomplete outcome data (attrition bias). We assessed the risk of bias from missing data as: low risk of bias (ITT analysis, or all participants accounted for with adequate reasons for loss and equally distributed between groups); low risk of bias (minimal loss of data); unclear risk of bias (other issues, such as cross-over studies); high risk of bias (completer analysis, attrition $10 \%$ or more).

5. Selective reporting (reporting bias). We assessed the risk of reporting bias as: low risk of bias (all intended outcomes reported); unclear risk of bias (any anomaly in reporting, such as participants contributing more than one set of data, or some outcomes not participant-reported); high risk of bias (prespecified outcome of interest not reported).

6. Size (checking for possible biases confounded by small size). Small studies may overestimate treatment effects, probably because the conduct of small studies is more likely to be less rigorous, allowing critical criteria to be compromised. We considered studies to be at low risk of bias if they had 200 participants or more per treatment arm, at unclear risk if they had 50 to 200 participants per treatment arm, and at high risk if they had fewer than 50 participants per treatment arm.

\section{Measures of treatment effect}

It was not possible to combine studies for meta-analysis to measure any treatment effect.

\section{Unit of analysis issues}

It was not possible to combine studies for meta-analysis and therefore no unit of analysis issues were encountered.

\section{Dealing with missing data}

We took a decision not to impute missing data.

\section{Assessment of heterogeneity}

No statistical assessment of heterogeneity was made as no metaanalysis was possible.

\section{Assessment of reporting biases}

We carried out extensive searches to identify relevant studies, but were unable to carry out any formal test for publication or other reporting biases.

\section{Data synthesis}

We did not pool data.

\section{Grading of evidence}

This section is taken from Cochrane Drugs and Alcohol recommended text. The overall quality of the evidence for each outcome was assessed using the GRADE system, and presented in Summary of findings for the main comparison, to present the main findings of a review in a transparent and simple tabular format. In particular, we included key information concerning the quality of evidence, the magnitude of effect of the interventions examined, and the sum of available data on the main outcomes.

The GRADE system uses the following criteria for assigning grade of evidence:

1. High: we are very confident that the true effect lies close to that of the estimate of the effect;

2. Moderate: we are moderately confident in the effect estimate; the true effect is likely to be close to the estimate of effect, but there is a possibility that it is substantially different;

3. Low: our confidence in the effect estimate is limited; the true effect may be substantially different from the estimate of the effect;

4. Very low: we have very little confidence in the effect estimate; the true effect is likely to be substantially different from the estimate of effect.

We downgraded the evidence for:

1. serious (-1) or very serious (-2) limitation to study quality;

2. important inconsistency $(-1)$;

3. some $(-1)$ or major (-2) uncertainty about directness;

4. imprecise or sparse data $(-1)$;

5. high probability of reporting bias $(-1)$.

In addition, where there were circumstances where the overall rating for a particular outcome needed to be adjusted as recommended by GRADE guidelines (Guyatt 2013a). For example, if there were so few data that the results were highly susceptible to the random play of chance, or if studies used last observation carried forward (LOCF) imputation in circumstances where there were substantial differences in adverse event withdrawals, one would have no confidence in the result, and would need to downgrade the quality of the evidence by 3 levels, to very low quality. In circumstances where there were no data reported for an outcome, we would report the level of evidence as very low quality (Guyatt 2013b).

\section{'Summary of findings' table}

We included a 'Summary of findings' table to present the main findings in a transparent and simple tabular format. We have included key information concerning the quality of evidence, the magnitude of effect of the interventions examined, and the sum of available data on the outcomes of participant-reported pain intensity and adverse events - appetite, thirst and somnolence.

\section{Subgroup analysis and investigation of heterogeneity}

We expected from previous versions of this review that the included studies would be heterogeneous and planned to undertake subgroup analysis based upon variations in methods such as titration schedule, route of administration, different comparators, and duration of studies. However no data were available for pooled analysis.

\section{Sensitivity analysis}

No sensitivity analysis was planned, or possible. 


\section{RESULTS}

\section{Description of studies}

\section{Results of the search}

We reviewed all the included and excluded studies in the earlier review, and carried out updated searches to May 2016. After deduplication and screening we assessed the full texts of 10 studies from the earlier review and four new studies identified by database searching. We subsequently identified one further potential paper from reference lists (Moksnes 2011) but this was excluded. Searches of ClinicalTrials.gov identified two studies, both of which had been terminated due to slow accrual, and were excluded from this review.

A flow chart of the process is shown in Figure 1 (Moher 2009).

\section{Included studies}

In this updated review, we included six studies, with 388 participants. Five of the nine included studies from the 2006 update are in this latest version (Beaver 1967; Bruera 2004; Mercadante 1998; Twycross 1977; Ventafridda 1986). One new study has been added (Mercadante 2008).

All studies were of adult participants with various types of cancer who required strong opioids to control their pain. Where reported the mean (or median) age was 48 to 65 years (range 18 to 87 ), and there were slightly more women than men in the studies (1.3:1). Most participants had previously been treated with World Health Organization (WHO) step 1 and 2 opioids (Ventafridda 1987), with inadequate response, but some had previously received step 3 opioids. Studies generally allowed titration to achieve the optimum balance of pain relief and adverse events. One study examined single doses of both intramuscular (IM) and oral morphine with some participants undergoing more than one round of treatments (Beaver 1967). The remaining studies used oral morphine.

Details of the individual studies are in the Characteristics of included studies table.

\section{Excluded studies}

We revised the excluded studies list for this update and this version of the review now excludes 11 studies. Four studies were included in the earlier review (Ferrer-Brechner 1984; Gourlay 1986; Grochow 1989; Matts 1964), and one was excluded (Morley 2003). The new excluded studies were two studies identified in ClinicalTrials.gov (both excluded because they recruited only a single participant, NCT00573937; NCT00726830); Cubero 2010 and Lauretti 2013 (both used methadone in combination with other agents); Raptis 2013 (not a trial of methadone); and Moksnes 2011 (a study of switching methods).

See Characteristics of excluded studies for further details.

\section{Risk of bias in included studies}

Two authors independently assessed risk of bias for each study using the criteria outlined in Assessment of risk of bias in included studies. Summaries of the risk of bias assessment are provided in Figure 2 and Figure 3. The risks of bias for the included studies are described here.

\section{Allocation}

All studies were randomised, but only two adequately described the method used to generate the random sequence (Bruera 2004; Mercadante 2008). One study described the method used to conceal allocation of the random sequence and we judged this to be at low risk of bias (Bruera 2004). The remaining studies were judged at unclear risk of bias.

\section{Blinding}

Three studies adequately described the method used to maintain blinding (Beaver 1967; Bruera 2004; Twycross 1977). Two of the studies were open-label and used commercial products so we judged them to be at high risk of bias (Mercadante 1998; Mercadante 2008). One study did not describe blinding and used different dosing regimens, and we judged it to be at high risk of bias (Ventafridda 1986).

\section{Incomplete outcome data}

We judged three studies to be at low risk of bias for this domain (Bruera 2004; Mercadante 1998; Twycross 1977), and two studies to be at high risk because they analysed only those who completed the study (Mercadante 2008; Ventafridda 1986). Beaver 1967 reported on participants who completed both cross-over phases, and we judged this study to be at high risk of bias.

\section{Selective reporting}

We judged two studies to be at an unclear risk of bias (Beaver 1967, Mercadante 1998); all others were judged to be at low risk for this domain.

\section{Other potential sources of bias}

We judged all the studies to be at high risk due to small numbers of participants per treatment arm.

\section{Effects of interventions}

See: Summary of findings for the main comparison Methadone compared to Morphine for cancer pain

A summary of results is presented in Appendix 2.

\section{Efficacy}

\section{Methadone compared with oral morphine}

\section{a) Intramuscular (IM) methadone compared with IM morphine}

A study by Beaver 1967 looked at 37 participants in a double-blind double-dummy cross-over comparisons of IM methadone and IM morphine. Pain relief was good in both groups at six hours, with higher doses producing 'no worse than mild pain'. Methadone was found to be slightly more potent than morphine.

\section{b) Oral methadone compared with immediate-release oral morphine}

Beaver 1967 also examined the efficacy of oral methadone and oral morphine in the IM study discussed above. However the study report does not provide separate data for the oral drugs. In a study of 66 participants by Ventafridda 1986, all who completed 14 days of treatment $(n=54)$ achieved 'no worse than mild pain'. We judged this to be very low-quality evidence because of the small size of the study, the lack of blinding, and use of completer analysis. 


\section{c) Oral methadone compared with modified-release oral morphine}

Three studies (215 participants) compared oral methadone with oral morphine, modified-release (MR) (Bruera 2004; Mercadante 1998; Mercadante 2008).

Bruera 2004 found that methadone at a daily dose of $15 \mathrm{mg}$ was not superior to $60 \mathrm{mg} /$ day of morphine MR. Pain reduction of at least $20 \%$ from baseline was the main pain outcome (methadone $24 / 49$, morphine $30 / 54$ at day 29). We judged this to be low-quality evidence because of the small size of the treatment groups. We could not derive data for 'no worse than mild pain'.

Mercadante 1998 reported mean pain scores that were just above 'no worse than mild pain' (See Appendix 2). In the second study by Mercadante (Mercadante 2008) similar mean pain scores were reported for participants who did not drop out (completer analysis). We judged this to be low-quality evidence because of the small size of the treatment groups, lack of blinding, and use of completer analysis in one study.

\section{Oral methadone compared with transdermal (TD) fentanyl}

In a three-arm study by Mercadante 2008, there were no reported differences in pain intensity between the methadone and TD fentanyl groups for participants who did not drop out.

\section{Oral methadone compared with diamorphine and cocaine combination}

Twycross 1977 compared methadone with a diamorphine-cocaine combination in 46 participants. The study examined the relative efficacy of the two interventions but no evaluable results were reported. Diamorphine-cocaine combinations are no longer used so the study is of historical interest only.

\section{Subgroup analysis}

There were insufficient data to carry out any subgroup analysis.

\section{Other efficacy measures}

None of the studies reported quality-of-life or treatmentsatisfaction outcomes.

\section{Adverse events}

\section{Specific adverse events}

The most frequently observed adverse events were dry mouth, somnolence, and constipation. We have separately presented adverse events relating to appetite, consciousness and thirst, as well as more general adverse events in Appendix 3. No study reported the effects of the intervention on appetite. Sedation or somnolence was reported with both morphine and methadone; the results were inconsistent across studies, but the incidence was generally higher with methadone than with morphine. Dry mouth was reported in three studies (Beaver 1967; Mercadante 1998; Ventafridda 1986), but again results were not consistent. Both morphine and methadone can produce a dry mouth and, by association, thirst. The majority of studies reported nausea, vomiting, and constipation.

We judged the quality of the evidence relating to adverse events as very low because of the small size of the studies, lack of blinding and use of completer analysis in some studies, the small number of events, and indirectness, since surrogates for appetite, thirst and somnolence (such as sedation, drowsiness and dry mouth) were used.

\section{Withdrawals due to adverse events, non compliance and death}

Adverse event withdrawals were uncommon (12/202) and similar between groups.

There were no recorded withdrawals for noncompliance.

Deaths were uncommon except in one study where the majority of participants died irrespective of the treatment group (Twycross 1977).

\section{DISCUSSION}

This is the second update of a review first published in 2004 and last updated in 2007. In this update, earlier decisions were revisited and current standards applied to the review.

\section{Summary of main results}

For studies in cancer pain, it is useful to know what proportion of people starting treatment are likely to be able to tolerate it, and what proportion of those who tolerate it are likely to obtain adequate pain relief. The studies did not report results in a way that unequivocally answered these questions.

Based on very limited amounts of data, there were no clear differences in participant-reported pain intensity or pain relief between methadone and morphine or transdermal fentanyl: similar proportions of participants were able to tolerate each drug and achieve a level of pain that was probably similar to mild pain. All six included studies were small, and in addition, three used methods that put them at risk of bias. The results must therefore be interpreted with caution.

We were not able to obtain reliable data on the numbers of participants who achieved no worse than mild pain.

Adverse events were typical for opioids (e.g. sedation, somnolence, dry mouth, constipation) but inconsistently reported.

\section{Overall completeness and applicability of evidence}

Given the use of methadone in palliative care the amount of underpinning data is small. The most recent study is now eight years old and most studies were conducted before 2000. The more recent studies (251 participants randomised) compared methadone with either modified-release morphine or transdermal fentanyl, which are commonly used in practice (Bruera 2004; Mercadante 1998; Mercadante 2008).

There were insufficient data to carry out any subgroup analysis. In particular, we were unable to investigate the influence of dose and titration regimen on either efficacy or tolerability. Included studies were underpowered to investigate serious adverse events, including arrhythmias.

We did not identify any studies in children.

\section{Quality of the evidence}

The evidence base identified by this review was small and limited in scope due to the small number of participants included and the diversity of the study methodologies and outcome reporting. Two 
of the more recent studies were at high risk of bias due to a lack of blinding (Mercadante 1998; Mercadante 2008).

\section{Potential biases in the review process}

We are unaware of any potential biases in the review process.

\section{Agreements and disagreements with other studies or reviews}

The search strategy for this updated review identified a systematic review conducted using Cochrane methods to examine the literature on methadone for cancer pain since the 2007 publication of this review (Good 2014). The review authors identified four randomised controlled trials. One is included in this update (Mercadante 2008). The other three were identified in our search strategy but have been allocated to the 'excluded studies' because they used methadone in combination with other agents (Lauretti 2013), or did not compare methadone with a different comparator. One examined outcomes for participants on a stable dose of morphine, who were switched to methadone with or without acetaminophen (paracetamol) (Cubero 2010). Good pain control and improved side-effect burden and quality of life were reported, with a majority of participants expressing a preference for methadone treatment. However this was not a trial that examined methadone use in the way we defined for our review, which explains our decision to exclude it. The other study identified by Good 2014 compared two methods of switching to methadone (Moksnes 2011). Whilst interesting, the study addressed a different question from that considered by this review.

\section{AUTHORS' CONCLUSIONS}

\section{Implications for practice}

\section{For patients with cancer pain}

There is limited evidence from RCTs that methadone is effective in managing severe pain due to cancer in adults. Given the issues of difficulties around titration to an effective dose and also the possibility of severe adverse effects (particularly cardiac arrhythmias), it is unlikely to have a role as the first line of treatment.

\section{For clinicians managing cancer pain}

Methadone is an opioid that has been used for many years to treat severe cancer pain although the evidence base from randomised controlled trials is sparse. If other opioids are not tolerated it may have a role, providing the issues of dose titration and possible severe adverse effects are considered. There is no information for use in paediatrics.

\section{For policy makers}

Methadone has a role if other opioids are not tolerated, providing the issues of dose titration and possible severe adverse effects are considered. There is no information for use in paediatrics.

\section{For organisations or bodies making decisions about funding treatment options}

Methadone has a place on formularies but needs to be managed by those clinicians specialising in pain management and palliative care.

\section{Implications for research}

\section{General implications}

Research in this patient population is challenging, and no large, high-quality trials with well-managed bias have been conducted. A further consideration is the question of whether, with the increased concerns about the adverse effects of methadone on the prolongation of the QT interval, and greater recognition of significant methadone-related drug interaction, methadone is likely to be used more widely than at present, even with further research. While it would be easy to suggest that further research is needed, in practice this is very unlikely to happen as this is an old drug and funding is not likely to be forthcoming.

\section{Implications for study design}

The major problem with research involving methadone relates to its unique pharmacological characteristics. Repeated dose studies using methadone at fixed dose intervals is potentially hazardous in the early phase of pain management in a switch from another opioid, or when treating opioid-naive patients.

\section{Implications for measurement and outcomes}

As the distribution of response to analgesics is often bimodal, we strongly recommend the collection of dichotomous data in preference to mean pain scores. Data should be available to allow the estimation of the proportion of participants who achieve no worse than mild pain, defined as below $30 \mathrm{~mm}$ on a $100 \mathrm{~mm}$ VAS pain-intensity scale. Adverse events should always be reported but we advocate specific reporting of events affecting appetite, thirst and consciousness in line with the Neuberger report (DH 2013).

Other considerations for future study design include:

1. use of standard and comparable pain intensity scores, which would allow closer comparison between different studies and potentially meta-analysis;

2. inclusion of patient-reported pain and other data only;

3. larger numbers of participants in studies where differentiation by pain syndrome has been attempted in order to answer the question as to whether methadone is particularly valuable in bone or neuropathic pain or other syndromes;

4. patient satisfaction and quality of life appraisal.

\section{ACKNOWLEDGEMENTS}

Dr Gavin Stewart kindly reviewed the text at an early stage and made editorial adjustments. He also provided guidance on the feasibility or otherwise of meta-analysis.

Cochrane Review Group funding acknowledgement: the National Institute for Health Research (NIHR) is the largest single funder of the Cochrane Pain, Palliative and Supportive Care Review Group (PaPaS). Disclaimer: the views and opinions expressed therein are those of the authors and do not necessarily reflect those of the NIHR, National Health Service (NHS), or the Department of Health. 


\section{REFERE N C E S}

\section{References to studies included in this review}

Beaver 1967 \{published data only\}

Beaver WT, Wallenstein SL, Houde RW, Rogers A. A clinical comparison of the analgesic effects of methadone and morphine administered intramuscularly, and of orally and parenterally administered methadone. Clinical Pharmacololgy and Therapeutics 1967;8(3):415-26. [PUBMED: 5338385]

Bruera 2004 \{published data only\}

Bruera E, Palmer JL, Bosnjak S, Rico MA, Moyano J, Sweeney C, et al. Methadone versus morphine as a first-line strong opioid for cancer pain: a randomized, double-blind study. Journal of Clinical Oncology 2004;22(1):185-92. [DOI: 10.1200/ JCO.2004.03.172]

\section{Mercadante 1998 \{published data only\}}

Mercadante S, Casuccio A, Agnello A, Serretta R, Calderone L, Barresi L. Morphine versus methadone in the pain treatment of advanced cancer patients followed up at home. Journal of Clinical Oncology 1998;16(11):3656-61. [PUBMED: 9817288]

Mercadante 2008 \{published data only\}

Mercadante S, Porzio G, Ferrera P, Fulfaro F, Aielli F, Verna L, et al. Sustained-release oral morphine versus transdermal fentanyl and oral methadone in cancer pain management. European Journal of Pain 2008;12:1040-6. [DOI: 10.1016/ j.ejpain.2008.01.013]

\section{Twycross 1977 \{published data only\}}

Twycross R. A comparison of diamorphine with cocaine and methadone (letter). British Journal of Clinical Practice 1977;4:691-93. [PUBMED: 69292]

\section{Ventafridda 1986 \{published data only\}}

Ventafridda V, Ripamonti C, Bianchi M, Sbanotto A, De Conno F. A randomized study on oral administration of morphine and methadone in the treatment of cancer pain. Journal of Pain and Symptom Management 1986;1(4):203-7. [DOI: 10.1016/ S0885-3924(86)80042-2]

\section{References to studies excluded from this review}

\section{Cubero 2010 \{published data only\}}

Cubero DIG, del Giglio A. Early switching from morphine to methadone is not improved by acetaminophen in the analgesia of oncologic patients: a prospective, randomized, doubleblind, placebo-controlled study. Supportive Care in Cancer 2010;18(2):235-42. [DOI: 10.1007/s00520-009-0649-8]

\section{Ferrer-Brechner 1984 \{published data only\}}

Ferrer-Brechner T, Ganz P. Combination therapy with ibuprofen and methadone for chronic cancer pain. American Journal of Medicine 1984;77(1A):78-83. [DOI: 10.1016/ S0002-9343(84)80023-6]

\section{Gourlay 1986 \{published data only\}}

Gourlay GK, Cherry DA, Cousins MJ. A comparative study of the efficacy and pharmacokinetics of oral methadone and morphine in the treatment of severe pain in patients with cancer. Pain 1986;25(3):297-312. [DOI: 10.1016/0304-3959(86)90234-4]

Grochow 1989 \{published data only\}

Grochow L, Sheidler V, Grossman S, Green L, Enterline J. Does intravenous methadone provide longer lasting analgesia than intravenous morphine? A randomised, double blind study. Pain 1989;38(2):151-7. [DOI: 10.1016/0304-3959(89)90233-9]

Lauretti 2013 \{published data only\}

Lauretti GR, Rizzo CC, Mattos AL, Rodrigues SW. Epidural methadone results in dose-dependent analgesia in cancer pain, further enhanced by epidural dexamethasone. British Journal of Cancer 2013;108(2):259-64. [DOI: 10.1038/bjc.2012.593]

Matts 1964 \{published data only\}

Matts SGF, Swan CHF, Wharton BA. Double blind trial of dextromoramide, methadone and pethidine in the treatment of severe pain. Postgraduate Medical Journal 1964;40:103-5. [PUBMED: 14122903]

\section{Moksnes 2011 \{published data only\}}

Moksnes K, Dale O, Rosland JH, Paulsen O, Klepstad P, Kaasa S. How to switch from morphine or oxycodone to methadone in cancer patients? A randomised clinical phase II trial. European Journal of Cancer 2011;47(16):2463-70. [DOI: 10.1016/ j.ejca.2011.06.047]

Morley 2003 \{unpublished data only\}

Morley JS, Bridson J, Nash TP, Miles JB, White S, Makin MK. Lowdose methadone has an analgesic effect in neuropathic pain: a double-blind randomized controlled crossover trial. Palliative Medicine 2003; Vol. 17, issue 7:576-87. [PUBMED: 14594148]

NCT00573937 \{unpublished data only\}

Prommer E (lead investigator). Methadone versus morphine for cancer related pain. clinicaltrials.gov/ct2/show/NCT00573937 (accessed 21 April 2016) 2016. [CTG: NCT00573937]

\section{NCT00726830 \{unpublished data only\}}

Fisch MJ (lead investigator). Methadone, morphine, or oxycodone in treating pain in patients with cancer. clinicaltrials.gov/ct2/show/NCT00726830 (accessed 21 April 2016) 2012. [CTG: NCT00726830]

\section{Raptis 2013 \{published data only\}}

Raptis E, Vadalouca A, Stavropoulou E, Argyra E, Melemeni A, Siafaka I. Pregabalin vs. opioids for the treatment of neuropathic cancer pain: a prospective, head-to-head, randomized, open-label study. Pain Practice 2014;14(1):32-42. [DOI: 10.1111/papr.12045]

\section{Additional references}

\section{Bruera 1991}

Bruera E, Fainsinger R, Moore M, Thibault R, Spoldi E, Ventafridda V. Local toxicity with subcutaneous methadone. 
Experience of two centers. Pain 1991;45(2):141-3. [DOI: 10.1016/0304-3959(91)90179-2]

\section{Bruera 2002}

Bruera $\mathrm{E}$, Sweeney $\mathrm{C}$. Methadone use in cancer patients with pain: a review. Journal of Palliative Medicine 2002;5(1):127-38. [DOI: 10.1089/10966210252785097]

\section{Cruciani 2008}

Cruciani RA. Methadone: to ECG or not to ECG.... That is still the question. Journal of Pain and Symptom Management 2008;36(5):545-52. [DOI: 10.1016/j.jpainsymman.2007.11.003]

\section{Davis 2001}

Davis MP, Walsh D. Methadone for relief of cancer pain: a review of pharmacokinetics, pharmacodynamics, drug interactions and protocols of administration. Supportive Care in Cancer 2001;9(2):73-83. [DOI: 10.1007/s005200000180]

\section{DH 2013}

Anon. More care, less pathway. A review of the Liverpool Care Pathway. Report by Baroness Julia Neuberger (Chair), available at www.gov.uk/government/uploads/system/uploads/ attachment_data/file/212450/Liverpool_Care_Pathway.pdf (accessed 21 April 2016).

\section{Fainsinger 1993}

Fainsinger R, Schoeller T, Bruera E. Methadone in the management of cancer pain: a review. Pain 1993;51(2):137-47. [DOI: 10.1016/0304-3959(93)90125-9]

\section{Gannon 1997}

Gannon C. The use of methadone in the care of the dying. European Journal of Palliative Care 1997;4(5):152-8.

\section{Good 2014}

Good P, Afsharimani B, Movva R, Haywood A, Khan S Hardy $J$. Therapeutic challenges in cancer pain management: a systematic review of methadone. Journal of Pain and Palliative Care Pharmacotherapy 2014;28(3):197-205. [DOI: 10.3109/15360288.2014.938883]

\section{Gorman 1997}

Gorman AL, Elliott KJ, Inturrisi CE. The d- and l-isomers of methadone bind to the non-competitive site on the N-methylD-aspartate (NMDA) receptor in rat forebrain and spinal cord. Neuroscience Letters 1997;223(1):5-8.

\section{Graner 2016}

Graner KM, Rolim GS, Moraes AB, Padovani CR, Lopes MA, Santos-Silva AR, et al. Feelings, perceptions, and expectations of patients during the process of oral cancer diagnosis. Support Care Cancer 2016;24:2323-32. [DOI: 10.1007/s00520-015-3030-0]

\section{Guyatt 2013a}

Guyatt G, Oxman AD, Sultan S, Brozek J, Glasziou P, AlonsoCoello P, et al. GRADE guidelines: 11 . Making an overall rating of confidence in effect estimates for a single outcome and for all outcomes. Journal of Clinical Epidemiology 2013;66(2):151-7. [DOI: 10.1016/j.jclinepi.2012.01.006]

\section{Guyatt 2013b}

Guyatt GH, Oxman AD, Santesso N, Helfand M, Vist G, Kunz R, et al. GRADE guidelines: 12 . Preparing summary of findings tables-binary outcomes. Journal of Clinical Epidemiology 2013;66(2):158-72. [DOI: 10.1016/j.jclinepi.2012.01.012]

\section{Hanks 1998}

Hanks GWC, Cherny N. Opioid analgesic therapy. In: Doyle D, Hanks GWC, MacDonald N editor(s). Oxford Textbook of Palliative Medicine. Oxford: Oxford University Press, 1998:331-51.

\section{Higgins 2011}

Higgins JPT, Altman DG, Sterne JAC (editors). Chapter 8: Assessing risk of bias in included studies. In: Higgins JPT, Green $\mathrm{S}$ (editors). Cochrane Handbook for Systematic Reviews of Interventions Version 5.1.0 (updated March 2011). The Cochrane Collaboration, 2011. Available from handbook.cochrane.org.

\section{Ma 2016}

Ma H, Liu Y, Huang L, Zeng XT, Jin SH, Yue GJ, et al. The adverse events of oxycodone in cancer-related pain: a systematic review and meta-analysis of randomized controlled trials. Medicine (Baltimore) 2016;95(15):e3341. [DOI: 10.1097/ MD.0000000000003341]

\section{Mathew 1999}

Mathew P, Storey P. Subcutaneous methadone in terminally ill patients: manageable local toxicity. Journal of Pain and Symptom Management 1999;18(1):49-52. [DOI: 10.1016/ S0885-3924(99)00020-2]

\section{Moher 2009}

Moher D, Liberati A, Tetzlaff J, Altman DG, The PRISMA Group. Preferred reporting items for systematic reviews and meta-analyses: the PRISMA statement. PLoS Medicine 2009;6(7):e1000097. [DOI: 10.1371/journal.pmed1000097]

\section{Payne 1998}

Payne R, Gonzales GR. Pathophysiology of pain in cancer and other terminal diseases. In: Doyle D, Hanks GWC, MacDonald N editor(s). Oxford Textbook of Palliative Medicine. Oxford: Oxford University Press, 1998:299-310.

\section{RevMan 2014 [Computer program]}

The Nordic Cochrane Centre, The Cochrane Collaboration. Review Manager (RevMan). Version Version 5.3. Copenhagen: The Nordic Cochrane Centre, The Cochrane Collaboration, 2014.

\section{Ripamonti 1997}

Ripamonti C, Zecca E, Bruera E. An update on the clinical use of methadone for cancer pain. Pain 1997;70(2-3):109-15. [DOI: 10.1016/S0304-3959(96)03286-1]

\section{Twycross 1998}

Twycross R, Wilcock A, Thorpe S. Palliative Care Formulary. Oxford: Radcliffe Medical Press, 1998. 


\section{Twycross 2014}

Twycross R, Wilcock A (Eds). PCF5 Palliative Care Formulary. Fifth. Nottingham: palliativedrugs.com Ltd, 2014. [ISBN: 978-0-9552547-9-6]

\section{van den Beuken-van Everdingen 2007}

van den Beuken-van Everdingen MH, de Rijke JM, Kessels AG, Schouten HC, van Kleef M, Patijn J. High prevalence of pain in patients with cancer in a large population-based study in The Netherlands. Pain 2007;132:312-20.

\section{van den Beuken-van Everdingen 2013}

van den Beuken-van Everdingen MH, Geurts JW, Patijn J. Prolonged QT interval by methadone: relevance for daily practice? A prospective study in patients with cancer and noncancer pain. Journal of Opioid Management 2013;9(4):263-7. [DOI: 10.5055/jom.2013.0167]

\section{Ventafridda 1987}

Ventafridda V, Tamburini M, Caraceni A, De Conno F, Naldi F. $A$ validation study of the WHO method for cancer pain relief. Cancer 1987;59(4):850-6. [PUBMED: 3802043]

\section{Weschules 2008}

Weschules DJ, Bain KT, Richeimer S. Actual and potential drug interactions associated with methadone. Pain Medicine 2008;9(3):315-44. [DOI: 10.1111/j.1526-4637.2006.00289.x]

\section{CHARACTERISTICS OF STUDIES}

Characteristics of included studies [ordered by study ID]

\section{Wiffen 2014}

Wiffen PJ, Derry S, Moore RA. Impact of morphine, fentanyl, oxycodone or codeine on patient consciousness, appetite and thirst when used to treat cancer pain. Cochrane Database of Systematic Reviews 2014, Issue 5. [DOI: 10.1002/14651858.CD011056.pub2]

\section{References to other published versions of this review Nicholson 2002}

Nicholson A, Davies A, Reid C. Methadone for cancer pain. Cochrane Database of Systematic Reviews 2002, Issue 11. [DOI: 10.1002/14651858.CD003971]

\section{Nicholson 2004}

Nicholson AB. Methadone for cancer pain. Cochrane Database of Systematic Reviews 2004, Issue 1. [DOI: 10.1002/14651858.CD003971.pub2]

\section{Nicholson 2007}

Nicholson AB. Methadone for cancer pain. Cochrane Database of Systematic Reviews 2007, Issue 10. [DOI: 10.1002/14651858.CD003971.pub3]

Beaver 1967

Methods Randomised, double-blind (double dummy), cross-over study

Single doses with assessment at $6 \mathrm{~h}$

Participants
$\begin{aligned} & \text { Chronic pain due to cancer } \\ & \text { Mean age } 48 \text { years (range } 34-59 \text { years) }\end{aligned}$

Interventions Morphine (IM or oral) or methadone (IM or oral) in a range of doses from $8 \mathrm{mg}$ to $48 \mathrm{mg}$

4 doses for each series and 4 different series

Outcomes
Pl: categorical scale (5 points), measured over $6 \mathrm{~h}$
Adverse events

Notes

\section{Risk of bias}

Authors' judgement Support for judgement 
Beaver 1967 (Continued)

Random sequence genera- Unclear risk Stated to be randomised
tion (selection bias)

Allocation concealment
(selection bias)

\begin{tabular}{|c|c|c|}
\hline $\begin{array}{l}\text { Blinding of participants } \\
\text { and personnel (perfor- } \\
\text { mance bias) }\end{array}$ & Low risk & $\begin{array}{l}\text { "in the oral-parenteral study both capsules and an injection, one of which was } \\
\text { a dummy, were administered" }\end{array}$ \\
\hline $\begin{array}{l}\text { Blinding of outcome as- } \\
\text { sessment (detection bias) } \\
\text { All outcomes }\end{array}$ & Low risk & $\begin{array}{l}\text { "in the oral-parenteral study both capsules and an injection, one of which was } \\
\text { a dummy, were administered" }\end{array}$ \\
\hline
\end{tabular}

\begin{tabular}{lll}
\hline $\begin{array}{l}\text { Incomplete outcome data } \\
\text { (attrition bias) } \\
\text { All outcomes }\end{array}$ & Only completed cross-overs were analysed for efficacy \\
\hline $\begin{array}{l}\text { Selective reporting (re- } \\
\text { porting bias) }\end{array}$ & Unclear risk & Some participants contributed more than one set of data \\
\hline Size & High risk & $<50$ participants per treatment arm \\
\hline
\end{tabular}

Bruera 2004

\begin{tabular}{|c|c|}
\hline Methods & Randomised, double-blind, parallel-group; duration 28 days \\
\hline \multirow[t]{6}{*}{ Participants } & $\begin{array}{l}\text { Outpatients with cancer pain determined by a validated clinical assessment. Differentiated between } \\
\text { neuropathic and non-neuropathic pain }\end{array}$ \\
\hline & $\begin{array}{l}\mathrm{N}=103 \text { patients randomised (methadone 49, morphine 54), } 66 \text { completed (methadone 29, morphine } \\
37 \text { ) }\end{array}$ \\
\hline & $M: 37, F: 66$ \\
\hline & $\begin{array}{l}\text { Age: methadone median age } 59 \text { years (range } 26-84 \text { years); morphine median age } 60 \text { years (range 31-87 } \\
\text { years) }\end{array}$ \\
\hline & Excluded participants who had previously been treated with strong opioids \\
\hline & All non-opioids discontinued on recruitment; titration of antiemetics and laxatives allowed \\
\hline \multirow[t]{2}{*}{ Interventions } & $\begin{array}{l}\text { Oral methadone } 7.5 \mathrm{mg} \text { twice daily with } 5 \mathrm{mg} \text { 4-hourly as needed. Oral morphine } 15 \mathrm{mg} \text { twice daily with } \\
5 \mathrm{mg} \text { 4-hourly as needed }\end{array}$ \\
\hline & $\begin{array}{l}\text { Titration based on use of 'as needed' doses and physicians' assessment daily for days } 1 \text { to } 8 \text {, then } \\
\text { weekly }\end{array}$ \\
\hline \multirow[t]{8}{*}{ Outcomes } & $\begin{array}{l}\text { Participant-reported data, daily on days } 1 \text { to } 8 \text {, then weekly thereafter: pain, sedation, confusion, nau- } \\
\text { sea, constipation, recorded on } 0-10 \text { NRS }\end{array}$ \\
\hline & $\begin{array}{l}\text { Weekly assessment of cognitive function (tool not specified) and global assessment of overall benefit } \\
\text { on VRS with } 7 \text { points and descriptors }\end{array}$ \\
\hline & End of study outcomes: \\
\hline & Pain response of $20 \%$ NRS reduction considered clinically relevant \\
\hline & $\begin{array}{l}\text { Composite toxicity calculated as sum of NRS for side effects - worsening by } 20 \% \text { or more considered } \\
\text { clinically relevant }\end{array}$ \\
\hline & Pain response and stable composite toxicity deemed to be 'obvious benefit' \\
\hline & Participant-reported global benefit - VRS 4 or more on 7-point scale \\
\hline & Adverse events \\
\hline
\end{tabular}


Bruera 2004 (Continued)

Notes

\section{Risk of bias}

\begin{tabular}{|c|c|c|}
\hline Bias & Authors' judgement & Support for judgement \\
\hline $\begin{array}{l}\text { Random sequence genera- } \\
\text { tion (selection bias) }\end{array}$ & Low risk & "generated centrally by computer generated numbers stratified by center" \\
\hline $\begin{array}{l}\text { Allocation concealment } \\
\text { (selection bias) }\end{array}$ & Low risk & $\begin{array}{l}\text { Pharmacy at each centre advised of treatment assigned but the code was kept } \\
\text { in a sealed envelope and not released to clinicians unless clinical emergency }\end{array}$ \\
\hline $\begin{array}{l}\text { Blinding of participants } \\
\text { and personnel (perfor- } \\
\text { mance bias) }\end{array}$ & Low risk & Stated to be double blind, "in identical capsules" \\
\hline $\begin{array}{l}\text { Blinding of outcome as- } \\
\text { sessment (detection bias) } \\
\text { All outcomes }\end{array}$ & Low risk & Stated to be double blind, "in identical capsules" \\
\hline $\begin{array}{l}\text { Incomplete outcome data } \\
\text { (attrition bias) } \\
\text { All outcomes }\end{array}$ & Low risk & $\begin{array}{l}\text { Similar rates of withdrawals in both groups and for similar reasons. BOCF for } \\
\text { dichotomised end points }\end{array}$ \\
\hline $\begin{array}{l}\text { Selective reporting (re- } \\
\text { porting bias) }\end{array}$ & Low risk & All intended outcomes reported upon \\
\hline Size & High risk & 49 participants in one arm and 54 in the other \\
\hline
\end{tabular}

Mercadante 1998

\begin{tabular}{ll}
\hline Methods & Prospective randomised parallel-group study \\
Participants treated until death
\end{tabular}

Participants
N $=40$
M: $19, \mathrm{~F}: 21$

Age: morphine mean age 65 years \pm 2.7 ; methadone mean age 61 years \pm 2.9

\begin{tabular}{ll} 
Interventions & Oral morphine modified-release, titrated to need \\
& Oral methadone solution, titrated to need \\
& Other palliative care drugs allowed including non-opioid analgesics. No anticancer therapy \\
\hline Outcomes & Pain intensity self report (when possible, otherwise doctor-rated) \\
& Symptoms related to cancer or adverse events \\
\hline Notes &
\end{tabular}

\section{Risk of bias}


Mercadante 1998 (Continued)

\begin{tabular}{|c|c|c|}
\hline Bias & Authors' judgement & Support for judgement \\
\hline $\begin{array}{l}\text { Random sequence genera- } \\
\text { tion (selection bias) }\end{array}$ & Unclear risk & Stated to be 'randomised' \\
\hline $\begin{array}{l}\text { Allocation concealment } \\
\text { (selection bias) }\end{array}$ & Unclear risk & Not stated \\
\hline $\begin{array}{l}\text { Blinding of participants } \\
\text { and personnel (perfor- } \\
\text { mance bias) }\end{array}$ & High risk & Commercially available products used \\
\hline $\begin{array}{l}\text { Blinding of outcome as- } \\
\text { sessment (detection bias) } \\
\text { All outcomes }\end{array}$ & High risk & Commercially available products used \\
\hline $\begin{array}{l}\text { Incomplete outcome data } \\
\text { (attrition bias) } \\
\text { All outcomes }\end{array}$ & Low risk & No problems identified \\
\hline $\begin{array}{l}\text { Selective reporting (re- } \\
\text { porting bias) }\end{array}$ & Unclear risk & $\begin{array}{l}\text { Some pain measurements may have been physician- or carer-assessed but not } \\
\text { clearly specified }\end{array}$ \\
\hline Size & High risk & 20 participants per treatment arm \\
\hline
\end{tabular}

\section{Mercadante 2008}

\begin{tabular}{|c|c|}
\hline Methods & $\begin{array}{l}\text { Multicentre, randomised, open, parallel-group study: duration } 4 \text { weeks } \\
\text { Fixed starting dose of study medication, adjusted to balance analgesia and adverse effects } \\
\text { Assessment at baseline and weekly intervals }\end{array}$ \\
\hline Participants & $\begin{array}{l}\text { Adults with advanced cancer requiring strong opioids who had received opioids for mild to moderate } \\
\text { pain, including tramadol and codeine at doses of at least } 300 \mathrm{mg} \text { and } 180 \mathrm{mg} \text { respectively, without ade- } \\
\text { quate analgesia. Expected survival } \geq 3 \text { months } \\
\text { Breast cancer was the most frequent diagnosis ( } 16 \text { participants), and mixed nociceptive-neuropathic } \\
\text { syndromes ( } 18 \text { participants) the most dominant pain type } \\
\mathrm{N}=108 \text { (70 completed) } \\
\text { M: } 36, \mathrm{~F}: 34 \text { (completers) } \\
\text { Mean age } 59 \text { years (range } 18-78 \text { ) (completers) }\end{array}$ \\
\hline Interventions & $\begin{array}{l}\text { Oral methadone, } 15 \mathrm{mg} / \mathrm{d} \text { in } 3 \text { divided doses, } \mathrm{n}=36 \\
\text { Modified-release oral morphine, initially } 60 \mathrm{mg} / \mathrm{d}, \mathrm{n}=36 \\
\text { Transdermal fentanyl patch, initially } 0.6 \mathrm{mg} / \mathrm{d}(25 \mu \mathrm{g} / \mathrm{h}), \mathrm{n}=36 \\
\text { Rescue medication: oral morphine at } 1 / 624-\mathrm{h} \text { oral equivalent requirement }\end{array}$ \\
\hline Outcomes & $\begin{array}{l}\text { Symptoms associated with opioid therapy (e.g. nausea, drowsiness, confusion): 4-point scale (not at } \\
\text { all, slight, a lot, severe) } \\
\text { Constipation: } 4 \text {-point scale ( } 0=1 \text { passage every } 1-2 \text { days, } 1=\text { one passage every } 3-4 \text { days, } 2=\text { one pas- } \\
\text { sage }>4 \text { days, } 3=\text { rectal measures) }\end{array}$ \\
\hline
\end{tabular}


Distress score calculated from sum of symptom intensities

PI: NRS (0-10)

Time to achieve dose stabilisation

Number of daily dose changes

Opioid escalation index

QoL using Spitzer QoL index (activity, daily life, health perceptions, social support, Behaviour rated on Likert 3-point scale (0-2)

Cost

Notes

Other medication for 'symptoms' were allowed during the study, which included anti-inflammatories, antidepressants and anticonvulsants, which may have an impact on pain; these were either continued or introduced as needed during the study

\section{Risk of bias}

\begin{tabular}{lll}
\hline Bias & Authors' judgement & Support for judgement \\
\hline $\begin{array}{l}\text { Random sequence genera- } \\
\text { tion (selection bias) }\end{array}$ & Low risk & "computer-generated" \\
\hline $\begin{array}{l}\text { Allocation concealment } \\
\text { (selection bias) }\end{array}$ & Unclear risk & Not described \\
\hline $\begin{array}{l}\text { Blinding of participants } \\
\text { and personnel (perfor- } \\
\text { mance bias) }\end{array}$ & High risk & Not blinded; used "commercially available" products \\
\hline $\begin{array}{l}\text { Blinding of outcome as- } \\
\text { sessment (detection bias) } \\
\text { All outcomes }\end{array}$ & High risk & Not blinded; used "commercially available" products \\
\hline $\begin{array}{l}\text { Incomplete outcome data } \\
\text { (attrition bias) }\end{array}$ & High risk & \\
\begin{tabular}{l} 
All outcomes \\
\hline $\begin{array}{l}\text { Selective reporting (re- } \\
\text { porting bias) }\end{array}$
\end{tabular} & Low risk & Efficacy data (group means) for participants remaining in study (completers). \\
\hline \begin{tabular}{l} 
Size \\
\hline
\end{tabular} & High risk & No problems identified \\
\hline
\end{tabular}

\section{Twycross 1977}

\begin{tabular}{ll}
\hline Methods & Randomised, double-blind, parallel-group: duration 4 weeks approximately \\
\hline Participants & Cancer pain; participants with terminal cancer with severe pain \\
$\mathrm{N}=46$. Gender mix stated to be 'comparable' \\
Median age 63 years
\end{tabular}

Interventions Diamorphine elixir with cocaine $10 \mathrm{mg}, \mathrm{n}=26$

Oral methadone, $\mathrm{n}=20$ 
Twycross 1977 (Continued)

Dose titrated to pain relief

\begin{tabular}{ll}
\hline Outcomes $\quad$ VAS for pain, nausea and mood, assessed twice daily \\
\hline Notes
\end{tabular}

\section{Risk of bias}

\begin{tabular}{|c|c|c|}
\hline Bias & Authors' judgement & Support for judgement \\
\hline $\begin{array}{l}\text { Random sequence genera- } \\
\text { tion (selection bias) }\end{array}$ & Unclear risk & "randomly allocated"; method not described \\
\hline $\begin{array}{l}\text { Allocation concealment } \\
\text { (selection bias) }\end{array}$ & Unclear risk & Not described \\
\hline $\begin{array}{l}\text { Blinding of participants } \\
\text { and personnel (perfor- } \\
\text { mance bias) }\end{array}$ & Low risk & "drugs were dispensed in undistinguishable solutions" \\
\hline $\begin{array}{l}\text { Blinding of outcome as- } \\
\text { sessment (detection bias) } \\
\text { All outcomes }\end{array}$ & Low risk & "drugs were dispensed in undistinguishable solutions" \\
\hline $\begin{array}{l}\text { Incomplete outcome data } \\
\text { (attrition bias) } \\
\text { All outcomes }\end{array}$ & Low risk & All participants accounted for \\
\hline $\begin{array}{l}\text { Selective reporting (re- } \\
\text { porting bias) }\end{array}$ & Low risk & No problems identified \\
\hline Size & High risk & $<50$ participants per treatment arm (20 and 26$)$ \\
\hline
\end{tabular}

\section{Ventafridda 1986}

\begin{tabular}{ll}
\hline Methods & Randomised, parallel-group: duration 14 days \\
\hline Participants & Advanced cancer requiring strong opioids for "excruciating pain" \\
$\mathrm{N}=66$ (randomised), 54 (completed) \\
M: $31, \mathrm{~F}: 23$ \\
\hline Oral methadone $1 \mathrm{mg} / \mathrm{ml}$, dose $8-28 \mathrm{mg}$ daily, given as divided dose every $6 \mathrm{~h}$ for $3 \mathrm{~d}$, then every $8 \mathrm{~h}, \mathrm{n}=$ \\
27 \\
Oral morphine $4 \mathrm{mg} / \mathrm{ml}$ dose $4-24 \mathrm{mg}$ every $4 \mathrm{~h}, \mathrm{n}=27$ \\
All participants received diclofenac $150 \mathrm{mg}$ daily and haloperidol 20 mg daily by injection \\
PI: 5-point categorical scale (converted to integrated pain score, which took into account duration) \\
Achieved no worse than mild pain (VAS $\leq 30 / 100)$ \\
Adverse events \\
Withdrawals
\end{tabular}


Ventafridda 1986 (Continued)

Notes

\section{Risk of bias}

\begin{tabular}{|c|c|c|}
\hline Bias & Authors' judgement & Support for judgement \\
\hline $\begin{array}{l}\text { Random sequence genera- } \\
\text { tion (selection bias) }\end{array}$ & Unclear risk & Stated to be "randomised", method not described \\
\hline $\begin{array}{l}\text { Allocation concealment } \\
\text { (selection bias) }\end{array}$ & Unclear risk & Method not described \\
\hline $\begin{array}{l}\text { Blinding of participants } \\
\text { and personnel (perfor- } \\
\text { mance bias) }\end{array}$ & High risk & Not described. Presumed open-label, since different dosing regimens \\
\hline $\begin{array}{l}\text { Blinding of outcome as- } \\
\text { sessment (detection bias) } \\
\text { All outcomes }\end{array}$ & High risk & Not described. Presumed open-label, since different dosing regimens \\
\hline $\begin{array}{l}\text { Incomplete outcome data } \\
\text { (attrition bias) } \\
\text { All outcomes }\end{array}$ & High risk & Completer analysis \\
\hline $\begin{array}{l}\text { Selective reporting (re- } \\
\text { porting bias) }\end{array}$ & Low risk & No problems identified \\
\hline Size & High risk & $<50$ participants per treatment arm \\
\hline
\end{tabular}

BOCF: baseline observation carried forward; F: female; h: hours; IM: intramuscular; M: male; mg: milligrams; N: number of participants in study; n: number of participants in treatment arm; NRS: Numerical Rating Scale; PI: pain intensity; QoL: quality of life; VAS: Visual Analogue Scale; VRS: Verbal Rating Scale

Characteristics of excluded studies [ordered by study ID]

\begin{tabular}{ll}
\hline Study & Reason for exclusion \\
\hline Cubero 2010 & Study of methadone in combination with acetaminophen (paracetamol) \\
\hline Ferrer-Brechner 1984 & 28 participants across 4 groups. Likely to be fewer than 10 participants per treatment group \\
\hline Gourlay 1986 & Fewer than 10 participants per treatment group \\
\hline Grochow 1989 & Fewer than 10 participants per treatment group \\
\hline Lauretti 2013 & Study of methadone in combination with other agents \\
\hline Matts 1964 & Not specifically cancer pain - only 15 out of 90 participants reported cancer-related pain \\
\hline Moksnes 2011 & Study of switching methods using methadone \\
\hline Morley 2003 & $\begin{array}{l}\text { Double-blind randomised controlled cross-over trial of methadone for neuropathic pain. Excluded } \\
\text { cancer pain }\end{array}$ \\
\hline NCT00573937 & Only 1 participant recruited \\
\hline
\end{tabular}




\section{Study Reason for exclusion}

NCT00726830 Only 1 participant recruited

Raptis $2013 \quad$ Not a study of methadone

\section{APPENDICES}

\section{Appendix 1. 2016 Search strategies}

\section{CENTRAL}

1. MESH DESCRIPTOR methadone EXPLODE ALL TREES (895)

2. (methadone or amidine or amidone or methadone or phenadone or heptadon or physeptone or eptadone or symoron or metasedin or sedo or ketalgine or "Martindale methadone mixture DTF" or methadose or methex or dolophine):TI,AB,KY (1857)

3. \#1 or \#2 (1867)

4. MESH DESCRIPTOR neoplasms EXPLODE ALL TREES (46032)

5. (neoplasm ${ }^{\star}$ or malignan* or tumour $^{\star}$ or tumor* or cancer $^{\star}$ or carcinoma*):TI,AB,KY (95750)

6. \#4 or \#5 (100496)

7. MESH DESCRIPTOR Pain EXPLODE ALL TREES (32221)

8. (pain* or nocicept ${ }^{\star}$ or neuropath $\left.{ }^{\star}\right): T I, A B, K Y(87637)$

9. \#7 or \#8 (93445)

10.3 AND \#6 AND \#9 (48)

\section{MEDLINE (via OVID)}

1. exp Methadone/ (11005)

2. (methadone or amidine or amidone or methadone or phenadone or heptadon or physeptone or eptadone or symoron or metasedin or sedo or ketalgine or "Martindale methadone mixture DTF" or methadose or methex or dolophine).mp. (14357)

3. 1 or 2 (14357)

4. exp Neoplasms/ (2821099)

5. (neoplasm* or malignan* or tumour ${ }^{\star}$ or tumor $^{\star}$ or cancer ${ }^{\star}$ or carcinoma*).mp. (3083681)

6. 4 or 5 (3400565)

7. exp Pain/ (328104)

8. (pain ${ }^{\star}$ or nocicept ${ }^{\star}$ or neuropath $\left.{ }^{\star}\right) \cdot m p .(636872)$

9. 7 or 8 (708138)

10.randomized controlled trial.pt. (413578)

11.controlled clinical trial.pt. (90546)

12.randomized.ab. (310481)

13.placebo.ab. (157686)

14.drug therapy.fs. (1847843)

15.randomly.ab. (219181)

16.trial.ab. (320971)

17.10 or 11 or 12 or 13 or 14 or 15 or 16 (2482796)

18.3 and 6 and 9 and 17 (319)

19.limit 18 to $y r=" 2006$-Current" (130)

\section{Embase (via OVID)}

1. exp Methadone/ (27180)

2. (methadone or amidine or amidone or methadone or phenadone or heptadon or physeptone or eptadone or symoron or metasedin or sedo or ketalgine or "Martindale methadone mixture DTF" or methadose or methex or dolophine).mp. (32962)

3. 1 or $2(32962)$ 
4. $\exp$ Neoplasms/ (3660745)

5. (neoplasm ${ }^{\star}$ or malignan* or tumour $^{\star}$ or tumor ${ }^{\star}$ or cancer $^{\star}$ or carcinoma*).mp. (4191612)

6. 4 or 5 (4648482)

7. exp Pain/ (974712)

8. (pain ${ }^{\star}$ or nocicept ${ }^{\star}$ neuropath*).mp. (1203279)

9. 7 or $8(1448357)$

10. (random* or factorial* or crossover or "cross over" or cross-over).tw. (1136282)

11. (placebo* or (doubl* adj blind $\left.{ }^{\star}\right)$ or $\left(\right.$ singl $^{*}$ adj blind $\left.\left.{ }^{*}\right)\right)$.tw. (307524)

12. (allocat* or allocat $\left.{ }^{\star}\right)$.tw. (103527)

13.crossover Procedure/ (46919)

14.double-blind procedure/ (130500)

15.single-blind procedure/ (22010)

16. Randomized Controlled Trial/ (402622)

17.10 or 11 or 12 or 13 or 14 or 15 or $16(1381772)$

18.3 and 6 and 9 and 17 (195)

19.limit 18 to yr="2006 -Current" (116)

\section{CINAHL (via EBSCO)}

1. MH methadone OR TX methadone or amidine or amidone or methadone or phenadone or heptadon or physeptone or eptadone or symoron or metasedin or sedo or ketalgine or "Martindale methadone mixture DTF" or methadose or methex or dolophine (3328)

2. MH neoplasms OR TX ( neoplasm* or malignan* or tumour ${ }^{\star}$ or tumor ${ }^{\star}$ or cancer ${ }^{\star}$ or carcinoma* $)(269,166$ )

3. MW pain OR TX ( pain ${ }^{\star}$ or nocicept* or neuropath* $)(173,682)$

4. S1 AND S2 AND S3 (214)

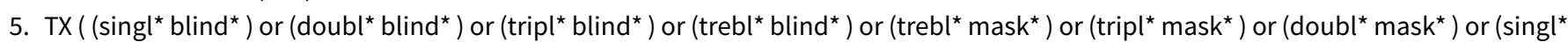
mask $^{\star}$ ) ) OR TX randomi\#ed control\$ trial\$ OR MH random assignment OR TX random allocat* OR TX placebo* OR MH Quantitative Studies OR TX allocat* random $^{\star}(725,719)$

6. S4 AND S5 (59)

\section{Appendix 2. Results}

\begin{tabular}{|c|c|c|c|c|c|}
\hline Study ID & Design & $\begin{array}{l}\text { Total Partici- } \\
\text { pants }\end{array}$ & No worse than mild pain & $\begin{array}{l}\text { Results } \\
\text { Methadone }\end{array}$ & $\begin{array}{l}\text { Results con- } \\
\text { trol }\end{array}$ \\
\hline Beaver 1967 & Cross-over & 37 & Not estimable & $N / A$ & $N / A$ \\
\hline Bruera 2004 & Parallel & 103 & Not estimable & $\begin{array}{l}>20 \% \text { im- } \\
\text { provement } \\
37 / 49\end{array}$ & $\begin{array}{l}>20 \% \text { im- } \\
\text { provement } \\
41 / 54\end{array}$ \\
\hline $\begin{array}{l}\text { Mercadante } \\
1998\end{array}$ & Parallel & 40 & $\begin{array}{l}\text { Pain score }<4 / 10 \text {. } \\
\text { Mean values morphine } 3.3+/-0.2 \text {, } \\
\text { methadone } 3.4+/-0.1\end{array}$ & $\mathrm{~N} / \mathrm{A}$ & $\mathrm{N} / \mathrm{A}$ \\
\hline $\begin{array}{l}\text { Mercadante } \\
2008\end{array}$ & Parallel & 108 & $\begin{array}{l}\text { At Wweek } 4 \text { mean pain for morphine } 2.5 \text { ( } 1.7 \\
-3.3) \text {, fentanyl } 2.4(2-2.8) \text { and methadone } \\
3.4(2.6-4.1) \text { (completers only) }\end{array}$ & $\mathrm{N} / \mathrm{A}$ & $\mathrm{N} / \mathrm{A}$ \\
\hline Twycross 1977 & Parallel & 46 & Not reported & $\begin{array}{l}\text { Survival } \\
\text { worse on } \\
\text { methadone }\end{array}$ & $\mathrm{N} / \mathrm{A}$ \\
\hline $\begin{array}{l}\text { Ventafridda } \\
1986\end{array}$ & Parallel & 54 & $\begin{array}{l}\text { All participants achieved no worse than mild } \\
\text { pain based on mean pain scores (completers } \\
\text { only) }\end{array}$ & $\mathrm{N} / \mathrm{A}$ & $N / A$ \\
\hline
\end{tabular}




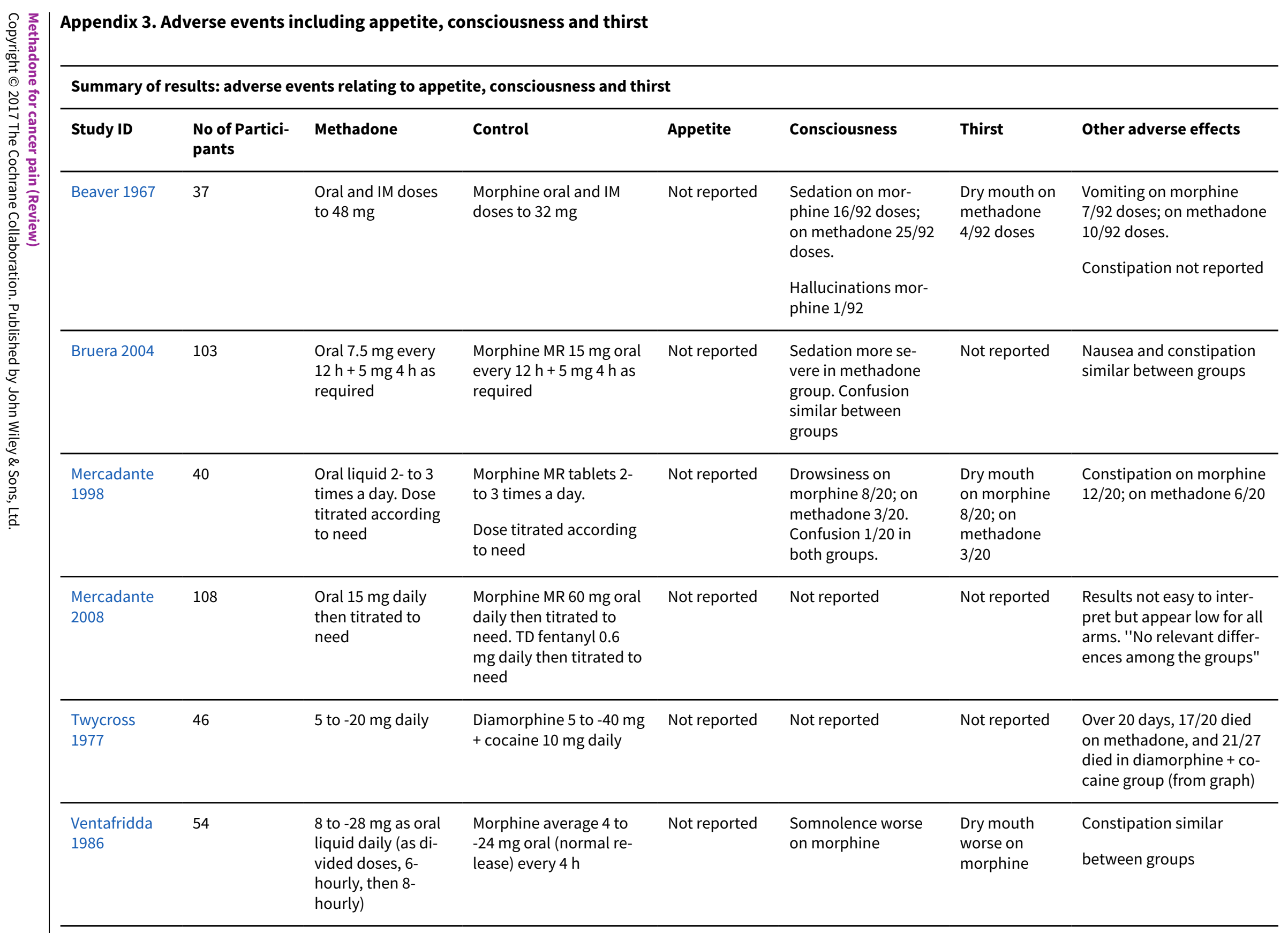



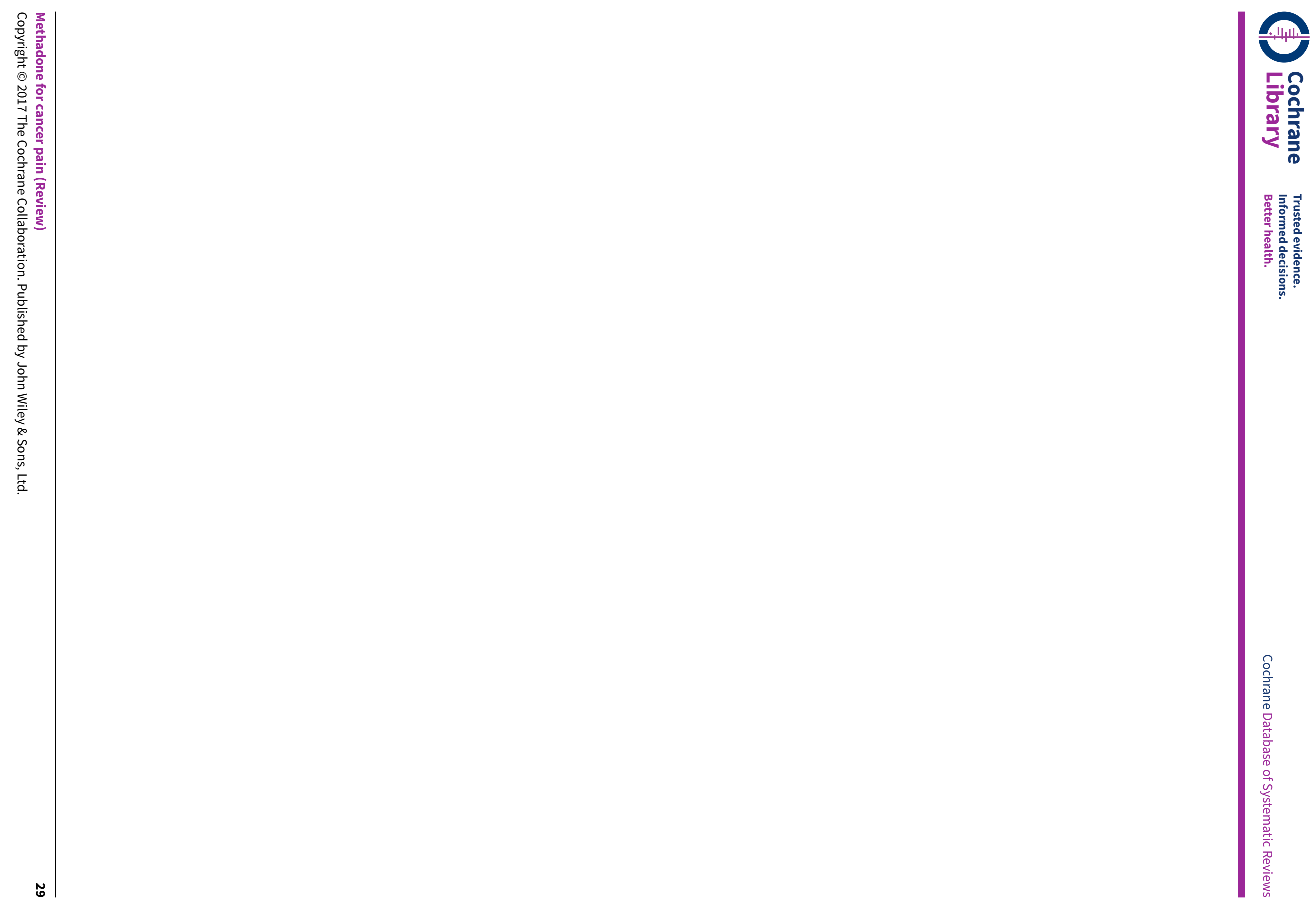


\section{WHAT'S NEW}

\begin{tabular}{lll}
\hline Date & Event & Description \\
\hline 13 February 2017 & Amended & Amended typo in appendix. \\
\hline
\end{tabular}

\section{H ISTORY}

Protocol first published: Issue 1, 2003

Review first published: Issue 2, 2004

\begin{tabular}{lll}
\hline Date & Event & Description \\
\hline 8 February 2017 & Review declared as stable & See Published notes. \\
\hline 4 May 2016 & $\begin{array}{l}\text { New citation required but conclusions } \\
\text { have not changed }\end{array}$ & $\begin{array}{l}\text { Review substantially revised and now includes } 6 \text { studies (5 from } \\
\text { earlier review, 1 new) with 388 participants. Conclusions not } \\
\text { changed. }\end{array}$ \\
\hline 4 May 2016 & New search has been performed & $\begin{array}{l}\text { New searches in May 2016, and original included and excluded } \\
\text { studies reassessed in line with current standards. }\end{array}$ \\
\hline August 2015 & New search has been performed & $\begin{array}{l}\text { This review has been updated to include results of new searches. } \\
\text { New risk of bias tables have been included and included studies } \\
\text { tables updated. }\end{array}$ \\
\hline July 2008 & Amended & \begin{tabular}{l} 
Converted to new review format. \\
\hline
\end{tabular}
\end{tabular}

\section{CONTRIBUTIONS OF AUTHORS}

GRW undertook the updated searches. GRW and ABN reviewed the search findings independently to determine studies which may meet the entry criteria and worked separately and then together to agree the final list. Subsequently SD and PW re-ran searches and suggested changes to the included studies list.

All review authors were involved in data extraction and writing the review.

\section{DECLARATIONS OF INTEREST}

$A B N$ : none known; $A B N$ is a palliative care specialist who manages patients with cancer and prescribes methadone.

GRW: none known.

SD: none known.

PW: none known.

\section{SOURCES OF SUPPORT}

\section{Internal sources}

- Oxford Pain Relief Trust, UK.

General institutional support 


\section{External sources}

- South Tees Hospitals NHS Foundation Trust, UK.

Time

- The National Institute for Health Research (NIHR), UK.

NIHR Cochrane Programme Grant: 13/89/29 - Addressing the unmet need of chronic pain: providing the evidence for treatments of pain

\section{DIFFERENCES BETWEEN PROTOCOLANDREVIEW}

Philip Wiffen and Sheena Derry joined the author team in 2016.

For this 2017 update we:

1. included participants with baseline pain of at least moderate intensity;

2. excluded small studies (fewer than 10 participants per treatment arm);

3. looked for the outcome 'no worse than mild pain';

4. specifically looked for adverse events related to consciousness, appetite and thirst;

5. expanded the 'risk of bias' section and included an assessment of the quality of the evidence using GRADE, in line with current standards for Cochrane reviews.

\section{N O T E S}

A new search within two years is not likely to identify any potentially relevant studies likely to change the conclusions. Therefore, this review has now been stabilised following discussion with the authors and editors. If appropriate, we will update the review if new evidence likely to change the conclusions is published, or if standards change substantially which necessitate major revisions.

\section{INDEX TERMS}

\section{Medical Subject Headings (MeSH)}

Analgesics, Opioid [ ${ }^{\star}$ therapeutic use]; Methadone [ ${ }^{\star}$ therapeutic use]; Morphine [therapeutic use]; Neoplasms [ ${ }^{\star}$ complications]; Pain [ ${ }^{\star}$ drug therapy] [etiology]; Pain Measurement; Randomized Controlled Trials as Topic

\section{MeSH check words}

Adult; Aged; Aged, 80 and over; Humans; Middle Aged 